\title{
PENINGKATAN KEMAMPUAN MENULIS MAHASISWA MELALUI MODEL PEMBELAJARAN KOOPERATIF TIPE JIGSAW
}

\section{STUDENTS' WRITING COMPETENCY IMPROVEMENT THROUGH JIGSAW COOPERATIVE LEARNING MODEL}

\author{
Raja Jasal Saleh \\ Balai Bahasa Provinsi Riau \\ Jl. Binawidya, Kompleks Universitas Riau, Panam, Pekanbaru 28293-Indonesia \\ e-mail: rajasaleh77@gmail.com
}

Diterima: 03 Mei 2017, dikembalikan untuk direvisi: 13 Mei 2017, disetujui: 25 Mei 2017

\begin{abstract}
Abstrak: Penelitian ini bertujuan untuk mengetahui kemampuan menulis mahasiswa melalui penerapan model pembelajaran kooperatif tipe Jigsaw. Metode penelitian ini adalah Penelitian Tindakan Kelas yang dilaksanakan selama dua siklus. Objek penelitian ini adalah mahasiswa UT Pekanbaru Semester VI Tahun Ajaran 2015. yang berjumlah 22 orang. Pengumpulan data dilakukan dengan teknik tes untuk memeroleh data kemampuan menulis mahasiswa dan teknik non-tes untuk memeroleh data observasi. Hasil observasi dianalisis secara kualitatif dengan mendeskripsikan setiap proses pembelajaran, baik aktivitas dosen maupun aktivitas mahasiswa. Hasil penelitian menunjukkan bahwa penerapan model pembelajaran kooperatif tipe jigsaw dapat meningkatkan kemampuan menulis mahasiswa dilihat dari jumlah mahasiswa yang tuntas setiap siklus. Pada siklus I, mahasiswa yang berada pada kategori tinggi hanya 4 orang (18,18\%), kategori sedang 18 orang (81,82\%), kategori rendah dan sangat rendah tidak ada, serta nilai rata-rata kelasnya 67,82. Namun pada siklus II, terjadi peningkatan. Mahasiswa yang berada pada kategori tinggi meningkat menjadi 9 orang (40,90\%), kategori sedang 13 orang (59,10\%), kategori rendah dan sangat rendah tidak ada, dan nilai rata-rata kelasnya mencapai 75,23.
\end{abstract}

Kata Kunci: Kemampuan menulis, jigsaw, pembelajaran kooperatif.

\begin{abstract}
This research is aimed to know the students' writing competency through jigsaw cooperative learning model. It is a Classroom Action Research carried out in two cycles. Research object is 22 sixth semester students of Pekanbaru Open University in 2015. academic year. Test is used to get the data of students' writing compentency, and non-test is used to get the observation data. Observation data is analized qualitatively by describing every learning process step by the lecturer as well as the students. The result shows that the implementation of the jigsaw cooperative learning model has improved the students' writing competency. It can can be seen from the number of students' achievement in the cycles. In the cylce I, 4 students $(18,18 \%)$ had high category score, 18 students $(81,82 \%)$ had middle category score, no students had low nor very low category scores, and the class average score was 67,82 . In the cycle II, there was some increase. Nine students (40,90\%) got high category score, 13 students $(59,10 \%)$ got average category score, no students got low nor very low category score, and the class average score got to be 75,23 .
\end{abstract}

Key Words: Writing competency, jigsaw, cooperative learning. 


\section{PENDAHULUAN}

Salah satu kesulitan yang dihadapi mahasiswa dalam menyelesaikan tugas perkuliahannya adalah membuat tugas akhir, yaitu skripsi, tesis, atau disertasi. Salah satu penyebabnya adalah tidak dimilikinya kemampuan yang memadai dalam menulis. Padahal, pada semester-semester awal mereka sudah banyak mendapatkan materi perkuliahan tentang menulis. Khusus di Universitas Terbuka (UT), mata kuliah yang berhubungan dengan kemampuan menulis adalah mata kuliah Keterampilan Menulis, Penelitian Tindakan Kelas (PTK), Bahasa Indonesia, Tugas Akhir Program (TAP), dan terakhir adalah Peningkatan Kemampuan Profesional (PKP).

Ketidakmampuan mahasiswa dalam menulis tersebut ditentukan oleh beberapa faktor yang berhubungan dengan mahasiswa, sistem perkuliahan, maupun dengan dosen. Terkait pada metode atau model yang digunakan, apabila metode atau model pembelajaran yang digunakan dosen kurang tepat dan tidak sesuai dengan materi pembelajaran, tujuan pembelajaran tentu akan sulit dicapai. Selain itu, mahasiswa UT pada umumnya adalah guru-guru honor dan/atau guru-guru yang melanjutkan pendidikan dari D-III ke S-I. Orientasi utama mereka hanya mengejar gelar sehingga motivasi belajar (keinginan menguasai materi) mereka cenderung rendah dan kegiatan pembelajaran akan semakin pasif.

Untuk merancang pembelajaran aktif, Uno (2012: 75) mengemukakan strategi pembelajaran, yaitu: (1) pembelajaran berpusat pada siswa; (2) pembelajaran terkait dengan kehidupan nyata; (3) pembelajaran mendorong anak berpikir tinggi; (4) pembelajaran melayani gaya belajar anak yang berbeda; dan (5) pembelajaran yang dapat menggunakan lingkungan sebagai media atau sumber belajar. Salah satu metode atau model pembelajaran yang dapat mendukung strategi tersebut adalah model pembelajaran kooperatif tipe Jigsaw.

Model pembelajaran ini diterapkan dalam rangka meningkatkan keterampilan menulis mahasiswa UT Pekanbaru tahun ajaran 2015. Melalui penelitian ini, mahasiswa diharapkan memeroleh pengalaman langsung sehingga bisa menerapkan metode Jigsaw ketika mereka kembali ke kelas untuk menyampaikan materi pembelajaran. Sebagai salah satu model pembelajaran yang kooperatif, Jigsaw mempunyai kelebihan, yaitu: (1) dapat mengembangkan hubungan antarpribadi positif di antara siswa yang memiliki kemampuan belajar berbeda; (2) menerangkan bimbingan secara teman; (3) rasa harga diri siswa yang lebih tinggi; (4) memperbaiki kehadiran; (5) penerimaan terhadap perbedaan individu lebih besar; (6) sikap apatis berkurang; (7) pemahaman materi lebih mendalam; dan (8) meningkatkan motivasi belajar (Pratiwi, 2009: 37).

Beberapa masalah yang teridentifikasi terkait rendahnya hasil belajar mahasiswa UT tersebut adalah: (1) dosen yang ditugasi untuk menyampaikan mata kuliah Keterampilan Menulis tidak semuanya memiliki latar belakang sebagai dosen Bahasa Indonesia atau mata kuliah yang membahas tentang menulis; (2) mahasiswa tidak membaca modul sebelum perkuliahan dimulai sehingga mahasiswa tidak memiliki pengetahuan awal terhadap materi dan tidak memerhatikan dosen yang sedang menyampaikan materi; dan (3) tugas-tugas yang diberikan dosen terkadang tidak sesuai dengan materi pembelajaran.

Alternatif pemecahan masalah antara lain adalah bahwa dosen mata kuliah Keterampilan Menulis harus berusaha meningkatkan hasil belajar mahasiswa dengan menerapkan model pembelajaran kooperatif tipe Jigsaw. Model pembelajaran kooperatif tipe Jigsaw ini sangat sesuai dengan karakteristik mata kuliah ini karena dalam mata kuliah ini secara umum 
membahas jenis cara menulis karya ilmiah. Berdasarkan permasalahan tersebut, perlu diadakan perbaikan pembelajaran yang salah satunya adalah melalui penelitian tindakan kelas (PTK). PTK adalah jenis penelitian yang sesuai dengan dosen atau tenaga pendidik karena fungsi PTK menurut Madya (2008: 5) adalah sebagai alat untuk membantu dosen/guru untuk mengatasi masalah-masalah yang didiagnosis dalam situasi pembelajaran di kelas dan membekali dosen/guru dengan keterampilan dan metode baru dan mendorong timbulnya kesadaran diri, khususnya melalui pengajaran teman sejawat.

Beberapa penelitian terdahulu yang terkait dengan penelitian ini di antaranya adalah:

Pertama, penelitian Ika Rahmaeta (2012) yang berjudul "Penerapan Pembelajaran Kooperatif Tipe Jigsaw untuk Meningkatkan Aktivitas dan Hasil Belajar Siswa Kelas V SD Negeri 04 Bulu Pemalang". Penelitian ini menyimpulkan bahwa penerapan pembelajaran kooperatif tipe jigsaw dapat meningkatkan aktivitas dan hasil belajar siswa.

Kedua, penelitian Syarif Hidayat (2011) yang berjudul "Peningkatan Kemampuan Menulis Karangan Deskripsi dengan Menggunakan Media Gambar". Melalui penelitian ini ditemukan bahwa penggunaan media gambar dapat meningkatkan kemampuan menulis siswa Kelas XI SMA Yapisa Nagrak.

Ketiga, penelitian Marsinta Dewi (2013) yang berjudul "Penerapan Metode Jigsaw dalam Pembelajaran Membaca Teks Biografi pada Siswa Kelas XI SMA". Penelitian ini menunjukkan bahwa penerapan metode jigsaw II dapat meningkatkan hasil belajar siswa SMA dan membuat siswa lebih aktif serta meningkat semangat bekerja sama dengan teman sekelas.

Berdasarkan latar belakang di atas, masalah dalam penelitian ini dirumuskan menjadi "apakah model pembelajaran kooperatif tipe Jigsaw dapat meningkatkan kemampuan menulis mahasiswa?" Dengan demikian, tujuan penelitian ini adalah untuk mengkaji kemampuan menulis mahasiswa UT Pekanbaru melalui penerapan model pembelajaran kooperatif tipe Jigsaw.

Penelitian ini diharapkan bermanfaat bagi: (1) mahasiswa, agar dapat meningkatkan kemampuan menulis mahasiswa semester VI UT Pekanbaru dan dapat meningkatkan semangat belajar mahasiswa agar mereka bisa lebih aktif dan terlibat dalam pembelajaran; (2) dosen/ peneliti, untuk mengadakan perbaikan cara dosen/tutor menyampaikan materi sehingga dosen/tutor akan merasa puas terhadap hasil yang diperolehnya dalam melaksanakan pembelajaran dan memberikan pengalaman baru bagi dosen dalam menyampaikan pembelajaran; (3) UT Pekanbaru, sebagai bahan alternatif pemecahan masalah yang terjadi di kelompok belajar (pokjar) UT, dengan banyaknya dosen/ tutor yang melaksanakan penelitian tindakan kelas ini diharapkan kualitas pendidikan dan khususnya pembelajaran akan meningkat; dan (4) peneliti lain, agar dapat menjadikan hasil penelitian ini sebagai bahan rujukan untuk melaksanakan penelitian-penelitian sejenis sehingga secara tidak langsung model pembelajaran kooperatif tipe Jigsaw yang dihasilkan penelitian ini akan tersosialisasikan dengan baik.

\section{KAJIAN LITERATUR}

Menurut Wardhani dan Wihardit (2007: 1.4), PTK adalah penelitian dalam bidang sosial yang menggunakan refleksi diri sebagai metode utama dan dilakukan oleh orang yang terlibat di dalamnya, serta bertujuan untuk melakukan perbaikan dalam bebagai aspek. PTK merupakan sebuah metode penelitian yang dilakukan di dalam kelas. Metode penelitian ini bertujuan untuk menanggulangi masalah yang dialami siswa maupun guru di dalam proses belajar mengajar pada kelas tertentu (Gesarina, 2013: 3). Dari dua pendapat tersebut dapat disimpulkan bahwa PTK 
adalah suatu jenis penelitian yang dilakukan guru berdasarkan refleksi diri, dilaksanakan di kelasnya sendiri, dan bertujuan untuk memperbaiki kinerja guru tersebut dalam melaksanakan proses pembelajaran sehingga meningkat hasil belajar mahasiswa.

Pelaksanaan PTK terhadap mahasiswa UT Pekanbaru memiliki tujuan untuk meningkatkan kemampuan menulis mereka. Hal ini dilaksanakan karena berdasarkan data dari semester-semester sebelumnya, kemampuan menulis mahasiswa UT secara umum masih rendah. Sementara itu, banyak sekali manfaat yang diperoleh bila seseorang memiliki kemampuan menulis yang baik, di antaranya adalah sarana untuk menemukan sesuatu, memunculkan ide baru, melatih kemampuan mengorganisasi informasi, melatih sikap objektif pada diri seseorang, membantu untuk menyerap dan memproses informasi, dan melatih berpikir aktif (Khadarsih, 2012: 15).

Kemampuan menulis dapat mendorong mahasiswa menemukan suatu topik dan mengembangkan gagasan menjadi suatu karangan yang diperlukan dalam kehidupan mereka. Melalui kegiatan menulis, diharapkan terbentuk proses berpikir dan berkreasi yang berperan dalam mengolah gagasan serta menjadi alat untuk menyampaikan gagasan (Sutarno, dkk., 2011:78).

Menulis merupakan suatu proses penyampaian gagasan, pesan, sikap, dan pendapat kepada pembaca dengan lambang bahasa yang dapat dilihat dan disepakati bersama oleh penulis dan pembaca. Hal ini sejalan dengan pemikiran Hidayat (2011:5) yang menyatakan bahwa menulis merupakan keterampilan seseorang dalam mengekspresikan pikiran dan perasaan yang disampaikan melalui bahasa tulis yang realisasinya berupa simbol-simbol grafis sehingga pembaca mampu memahami pesan yang terkandung di dalamnya. Dengan demikian, menulis adalah suatu keterampilan dan setiap orang memiliki potensi untuk menulis.

Pembelajaran menulis merupakan kemampuan paling sulit untuk dikuasai oleh mahasiswa dibandingkan dengan keterampilan berbahasa yang lain (Sulasdi, dkk., 2011:70). Menulis merupakan suatu keterampilan berbahasa terpadu yang ditujukan untuk menghasilkan tulisan. Sering dijumpai bahwa seorang mahasiswa dalam penguasaan materi bahasa yang lain sangat baik, tetapi sangat sulit menghasilkan sebuah tulisan yang berkualitas, bahkan hanya sekadar menghasilkan sebuah tulisan biasa.

Kemampuan menulis inilah yang ditingkatkan melalui model pembelajaran kooperatif Tipe Jigsaw. Masriyah (2012: 17) menyatakan bahwa Tipe Jigsaw adalah model belajar kooperatif yang menitikberatkan pada kerja kelompok siswa dalam bentuk kelompok kecil. Mahasiswa tidak hanya mempelajari materi yang diberikan, melainkan harus juga siap memberikan dan mengajarkan materi tersebut kepada anggota kelompoknya yang lain. Dengan demikian, mahasiswa saling tergantung satu dengan yang lain dan harus bekerja sama untuk mempelajari materi yang ditugaskan.

Materi dalam mata kuliah Keterampilan Menulis merupakan bacaan dan kiat-kiat dalam menulis sehingga sangat sesuai apabila diterapkan pembelajaran kooperatif tipe Jigsaw. Hal ini sesuai dengan pendapat Hertiavi, dkk. (2010:12) yang menyatakan bahwa pembelajaran kooperatif tipe Jigsaw sesuai apabila diterapkan pada materi-materi yang tidak banyak memuat rumus atau persamaan tetapi lebih banyak memuat teori.

Dalam tipe Jigsaw, mahasiswa dikelompokkan ke dalam kelompok-kelompok kecil (4-6 orang) yang disebut dengan "kelompok asal". Kemudian, masing-masing mahasiswa yang tergabung dalam kelompok asal tersebut menyebar dan bergabung dengan kelompok asal 
yang lain dengan materi yang sama. Kelompok yang baru tersebut dinamakan dengan "kelompok ahli". Setelah berdiskusi dan membahas materi di "kelompok ahli", mereka kembali ke kelompok asal untuk saling mengajarkan apa yang telah mereka bahas pada kelompok ahli. Jadi, sangat jelas bahwa ada saling ketergantungan positif antar mahasiswa di kelompok asal. Terakhir, masing-masing kelompok asal akan bertugas mempresentasikan hasil diskusinya.

\section{METODE PENELITIAN}

Metode penelitian yang digunakan adalah Penelitian Tindakan Kelas (PTK) yang bertujuan untuk memperbaiki kinerja dosen sehingga proses pembelajaran berlangsung lebih efektif. Subjek penelitian ini adalah mahasiswa semester VI FKIP PGSD pokjar Sukajadi, Pekanbaru yang berjumlah 22 orang. Penelitian ini dilaksanakan di SD Negeri 20 Pekanbaru yang beralamat di Jalan Kulim, Kecamatan Senapelan, Pekanbaru.

Penelitian ini dilaksanakan dengan sistem siklus, yaitu siklus I dan siklus II. Setiap siklus terdiri dari dua kali pertemuan dan mengacu pada tahapan-tahapan dalam melaksanakan PTK. Tahapan-tahapan tersebut adalah perencanaan, pelaksanaan, observasi, dan refleksi yang dikembangkan oleh Kemmis dan Taggart (1992: 14) seperti disajikan pada Gambar 1.

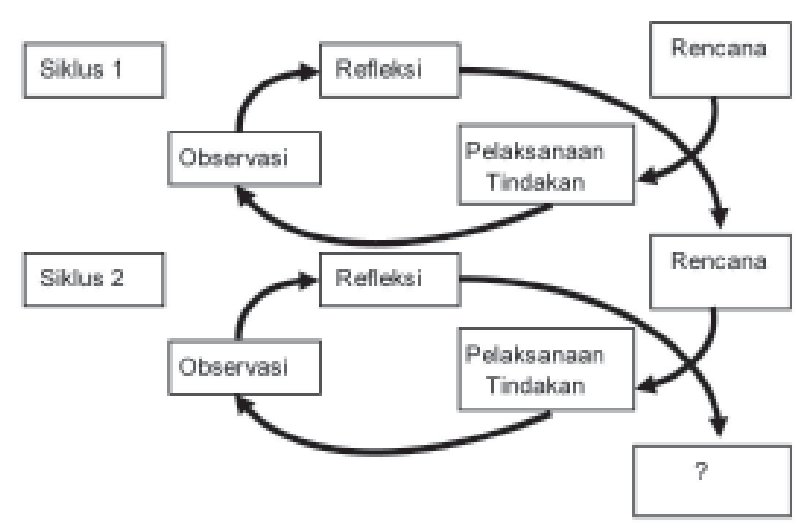

Gambar 1. Siklus PTK
Data penelitian ini terdiri dari dua jenis, yaitu data hasil observasi dan data kemampuan menulis mahasiswa UT Pekanbaru pada mata kuliah Keterampilan Menulis. Data hasil observasi juga terdiri dari dua, yaitu data hasil observasi kegiatan dosen dan data observasi terhadap kegiatan mahasiswa. Data hasil observasi dosen dan mahasiswa dianalisis dengan cara mendeskripsikan setiap kegiatan dosen dan mahasiswa selama proses belajarmengajar berlangsung. Indikator penilaian terhadap karangan mahasiswa adalah ide/topik karangan (20\%), isi (40\%), EYD (20\%), dan sistematika penulisan (20\%). Setiap item diberikan skor untuk mengetahui ketuntasan mahasiswa secara individu; sedangkan ketuntasan secara klasikal dihitung dengan rumus berikut ini.

$$
X=\frac{\sum X}{N}
$$

(Sudjana, 2009 dalam Sopandi, 2013: 45)

Keterangan

$X=$ Rata-rata kelas

" $X=$ Jumlah seluruh skor

$N$ = Banyaknya siswa

\section{HASIL DAN PEMBAHASAN}

Seperti yang telah dijelaskan pada bagian sebelumnya bahwa penelitian ini adalah PTK yang mengkondisikan mahasiswa untuk menulis karangan deskripsi, narasi, dan argumentasi pada siklus I serta karangan eksposisi dan persuasi pada siklus II. Untuk memeroleh hasil belajar yang lebih memuaskan dan mengatasi masalah-masalah yang terjadi selama ini, maka diterapkanlah model pembelajaran kooperatif tipe jigsaw dalam menyampaikan materi perkuliahan Keterampilan Menulis kepada mahasiswa Semeter VI UT Pekanbaru.

Berdasarkan penerapan model pembelajaran tersebut, berikut ini diuraikan hasil perbaikan 
pembelajaran yang dilaksanakan berdasarkan tahapan-tahapan PTK. Pemaparan hasil penelitian ini mengacu pada pelaksanaan pembelajaran selama empat kali pertemuan terakhir dengan mahasiswa. Untuk diketahui, materi yang terdapat dalam modul mata kuliah Keterampilan Menulis adalah hakikat menulis, kalimat efektif, paragraf, surat (surat dinas), paragraf I dan paragraf II. Masing-masing paragraf I dan II terdiri dari dua kali pertemuan. Pada materi paragraf I dan paragraf II (empat pertemuan terakhir) inilah dilaksanakan PTK dengan model pembelajaran kooperatif tipe Jigsaw. Pada materi paragraf I dan paragraf II dibahas jenis-jenis karangan dan segala sesuatu yang terkait dengan karangan.

Berikut adalah uraian pelaksanaan pembelajaran dari masing-masing siklus dan masing-masing pertemuan.

\section{Siklus I}

\section{Pertemuan Pertama (Sabtu, 17 Oktober 2015)}

Pertemuan pertama dilaksanakan pada hari Sabtu, 17 Oktober 2015. Materi perkuliahan pada pertemuan pertama ini adalah Paragraf I. Muatan pada materi ini adalah karangan deskripsi dan narasi. Untuk menerapkan tindakan, dosen mengacu pada empat langkah dalam PTK.

Pertama, pada tahap perencanaan, ada beberapa hal yang disiapkan oleh dosen, di antaranya adalah Rencana Perbaikan Pembelajaran (RPP) dan perangkat pembelajaran lainnya. Untuk menyusun RPP, dosen terlebih dahulu berkonsultasi dengan teman sejawat agar RPP yang disusun benarbenar bisa mengatasi pemasalahan yang terjadi di dalam kelas. RPP disusun sesuai dengan materi untuk pertemuan pertama, yaitu karangan deskripsi dan narasi.

Selain RPP, dosen juga menyiapkan beberapa contoh karangan deskripsi dan narasi untuk dijadikan sebagai media pembelajaran.
Pada tahap perencanaan ini, dosen membaca kembali langkah-langkah dalam pelaksanaan tipe Jigsaw. Hal ini bertujuan agar dosen benarbenar menguasai model pembelajaran tersebut. Satu hal yang menjadi kekhawatiran adalah pada langkah pembagian kelompok ahli, karena mahasiswa belum terbiasa dengan model pembelajaran ini.

Kedua, tahap pelaksanaan, dibagi menjadi tiga langkah kegiatan pembelajaran, yaitu: kegiatan awal, kegiatan inti, dan kegiatan akhir. Kegiatan awal dimulai saat dosen memasuki ruang kelas sesuai dengan jadwal yang telah ditentukan. Di dalam kelas, terlihat mahasiswa masih sibuk saling bercengkerama. Kelihatannya ada sesuatu yang dibicarakan mahasiswa. Semuanya terhenti ketika dosen masuk kelas. Dosen kemudian menyapa dengan menanyakan kabar mahasiswa. Dengan serentak mahasiswa merespons pertanyaan dosen. Kemudian dosen memeriksa kehadiran mahasiswa, ternyata masih ada dua orang mahasiswa yang belum hadir. Selanjutnya, dosen mulai membuka pembelajaran dengan menyampaikan tujuan pembelajaran yang harus dicapai dan memberikan apersepsi terhadap mahasiswa.

Pada kegiatan inti, dosen menjelaskan tentang tipe Jigsaw yang diterapkan selama beberapa hari. Dosen menjelaskan langkahlangkah pembagian kelompok asal dan kelompok ahli. Setelah mahasiswa paham tentang sistem pembagian kelompok, dosen kemudian masuk pada materi pembelajaran yang dibahas. Dosen mengawali dengan menjelaskan sekilas tentang karangan deskripsi dan narasi, mulai dari pengertian, ciri-ciri, dan sebagainya. Kemudian, dosen mengajak mahasiswa bertanya jawab tentang kedua jenis karangan tersebut. Ketika diberikan kesempatan untuk bertanya pada kegiatan pertama ini, tidak ada mahasiswa yang bertanya. Mereka terlihat masih malu-malu untuk mengeluarkan pendapat. 
Namun, dosen maklum dengan situasi ini dan mencoba untuk terus mengajak mahasiswa berdiskusi.

Selanjutnya, dosen mulai pada langkah tipe Jigsaw. Dosen membagi mahasiswa ke dalam empat kelompok yang heterogen. Dua kelompok beranggotakan 6 orang dan dua kelompok lainnya beranggotakan 5 orang. Kemudian, masing-masing anggota kelompok diberikan materi yang berbeda. Mahasiswa 1 sampai mahasiswa 5 atau 6 pada setiap kelompok memeroleh materi karangan (antara deskripsi dan narasi), tetapi dengan judul yang berbeda dan demikian seterusnya untuk kelompok lain.

Setelah mahasiswa mendapatkan materi yang berbeda, dosen menginstruksikan untuk membentuk kelompok ahli. Mahasiswa yang memiliki materi yang sama, bergabung dalam kelompok ahli. Di kelompok ahli, mereka berdiskusi dan mengerjakan tugas-tugas yang diberikan dosen kepada mereka. Hal-hal yang didiskusikan adalah menentukan jenis karangan, menentukan alur cerita, menemukan tokoh-tokoh dalam cerita, dan menjelaskan latar kejadian cerita (narasi). Tugas yang diberikan untuk mahasiswa yang memeroleh materi karangan deskripsi adalah mencari gambaran objek yang nyata, pelukisan terhadap suatu objek, dan keobjektifan terhadap benda yang dideskripsikan.

Setelah berdiskusi di kelompok ahli, mahasiswa kembali ke kelompok asal. Masingmasing anggota mempresentasikan hal-hal yang telah dibahasnya di kelompok ahli agar semua kelompok mendapatkan materi tesebut. Setelah mahasiswa saling berbagi informasi berdasarkan hasil diskusi pada kelompok ahli, semua informasi tersebut digabungkan untuk dijadikan sebagai presentasi kelompok. Kemudian, masing-masing kelompok asal diberikan waktu untuk mempresentasikan hasil diskusinya dan kelompok lain diberikan kesempatan untuk menanggapi hasil presentasi temannya.
Kegiatan akhir, di akhir pembelajaran pada pertemuan pertama, dosen dan mahasiswa secara bersama-sama merangkum pembelajaran. Poin-poin penting yang terkait dengan karangan deskripsi dan narasi dijelaskan ulang oleh dosen. Kemudian dosen memberikan tugas untuk dikerjakan di rumah. Pada pertemuan pertama tidak ada pengambilan nilai yang dilakukan di dalam kelas.

Ketiga, berdasarkan hasil observasi terhadap dosen yang telah dirangkum dalam lembar observasi dosen, diketahui bahwa dosen tidak menjelaskan sepenuhnya tentang sistem pembagian kelompok, baik kelompok asal maupun kelompok ahli. Hal ini sangat membingungkan mahasiswa, apalagi ketika mereka diminta dosen untuk membentuk kelompok ahli. Mereka berpikir bahwa mereka sudah memiliki kelompok. Banyak waktu terbuang pada saat pembagian kelompok ahli tersebut, karena mahasiswa tidak begitu mengerti instruksi dari dosen.

Hasil observasi terhadap mahasiswa menunjukkan bahwa mereka kebingungan terhadap metode pembelajaran yang diterapkan dosen karena di luar kebiasaan yang dilakukan dosen. Selama ini, dosen hanya berceramah dan mengadakan diskusi dengan mahasiswa. Saat ini, dosen sedikit sekali menjelaskan materi, dan mereka harus mencari sendiri. Pada saat diskusi juga terlihat bahwa banyak mahasiswa yang tidak serius sehingga mereka merasa kesulitan ketika mereka harus menceritakan hasil diskusi di kelompok ahli kepada temannya di kelompok asal.

Keempat, berdasarkan hasil refleksi, ditemukan bahwa kelemahan dosen adalah tidak mengadakan pengenalan materi pembelajaran pada saat kegiatan awal. Pada saat kegiatan inti, kesalahan dosen yang paling jelas adalah tidak menyampaikan teknik pembagian kelompok yang mengakibatkan kebingungan pada mahasiswa. Selain itu, kelemahan yang masih terjadi adalah 
mahasiswa belum serius dalam berdiskusi pada kelompok ahli karena mereka belum menyadari bahwa mereka akan menceritakan hasil pembahasannya di kelompok ahli.

\section{Pertemuan Kedua (Sabtu, 24 Oktober 2015)}

Pertemuan kedua ini dilaksanakan berdasarkan RPP yang dibuat dosen. Materi untuk pertemuan kedua masih sama dengan pertemuan pertama, tetapi dengan jenis karangan yang berbeda. Jenis karangan pada pertemuan kedua adalah karangan argumentasi. Kelemahan-kelemahan yang masih terjadi pada pertemuan pertama dicoba diatasi pada pertemuan kedua. Berikut adalah uraian pertemuan kedua berdasarkan langkah-langkah PTK.

Pertama, perencanaan sama dengan pada pertemuan pertama. Pada tahap perencanaan pertemuan kedua, dosen juga menyiapkan segala sesuatu yang berhubungan dengan pembelajaran yang dilaksanakan. Dosen mempersiapkan RPP yang digunakan sebagai acuan dalam melaksanakan pembelajaran. RPP pada pertemuan kedua ini sesuai dengan materi karangan argumentasi. Selain RPP, dosen juga menyiapkan beberapa contoh karangan sebagai sumber belajar bagi mahasiswa. Kemudian, dosen menjelaskan teknik pembagian kelompok dalam tipe Jigsaw karena hal inilah yang merupakan kelemahan dosen pada pertemuan pertama.

Kedua, pelaksanaan sesuai dengan jadwal. Tahap pelaksanaan dibagi ke dalam tiga langkah kegiatan pembelajaran, yaitu kegiatan awal, kegiatan inti, dan kegiatan akhir. Kegiatan awal dimulai pada saat dosen memasuki kelas bersama-sama dengan teman sejawat. Dosen langsung menuju meja di bagian depan dan teman sejawat menuju meja bagian belakang untuk mengobservasi proses pembelajaran. Kemudian, dosen menyampaikan salam dan menyapa serta memeriksa kehadiran mahasiswa. Mahasiswa dengan semangat menjawab salam dosen. Dosen memberikan apersepsi yang juga dikaitkan dengan materi perkuliahan. Di bagian akhir kegiatan awal, dosen menyampaikan tujuan pembelajaran dan mengaitkan antara materi yang telah dipelajari dengan materi yang akan dipelajari.

Pada kegiatan inti ini, dosen memulai pembelajaran dengan memberikan pertanyaan tentang karangan argumentasi. Ada dua orang mahasiswa yang mau memberikan komentar terkait dengan materi bahasan. Walaupun dengan jawaban yang kurang tepat, tetapi dosen tetap memberikan umpan balik terhadap jawaban mahasiswa. Selanjutnya, dosen menjelaskan pengertian, ciri-ciri, dan lain-lain tentang jenis karangan argumentasi. Mahasiswa terlihat lebih serius menyimak penjelasan dosen sambil sesekali bertanya. Pada tahap penjelasan, mahasiswa sudah lebih terbuka daripada ketika pada pertemuan pertama. Sudah ada sebagian mahasiswa yang memberikan pendapat tentang karangan argumentasi ini. Akhirnya diskusi, baik antara mahasiswa dan dosen maupun sesama mahasiswa sudah mulai terlihat.

Setelah berdiskusi secara singkat, dosen menerapkan tipe Jigsaw yang sebelumnya sudah dijelaskan dosen secara lebih rinci. Mahasiswa dibagi menjadi 4 kelompok asal. Dua kelompok beranggotakan 5 orang dan dua kelompok lainnya berjumlah 6 orang. Kemudian, mahasiswa diberikan materi berupa karangankarangan argumentasi dengan judul yang berbeda-beda dalam satu kelompok asal. Artinya, ada 5 atau 6 judul karangan argumentasi untuk satu kelompok. Setelah mendapatkan materi, dosen menginstruksikan untuk membentuk kelompok ahli. Dalam waktu yang singkat, semua mahasiswa sudah bergabung di kelompok ahli dengan materi yang sama. Kemudian mereka mendiskusikan materi 
kelompok masing-masing.

Setelah berdiskusi pada kelompok ahli, mereka kembali ke kelompok asal. Di kelompok asal, suasana kelas menjadi ribut. Setiap mahasiswa menceritakan hasil diskusinya di kelompok ahli ke teman-temannya di kelompok asal. Setiap kelompok membuat rangkumanrangkuman informasi yang diperoleh dari setiap anggota kelompok. Rangkuman-rangkuman tersebut digabung untuk dijadikan sebagai bahan presentasi kelompok asal. Langkah berikutnya, setiap kelompok melaksanakan presentasi secara bergiliran dan kelompok lain memberikan masukan.

Setelah semua kelompok tampil, mahasiswa ditugaskan untuk membuat satu paragraf karangan argumentasi dan dikerjakan di dalam kelas. Hasil pekerjaan mahasiswa pada pertemuan kedua ini dijadikan sebagai data siklus I. Kemudian, dari data ini akan diketahui peningkatan kemampuan menulis mahasiswa yang diajarkan melalui tipe Jigsaw.

Pada kegiatan akhir, dosen bersama-sama dengan mahasiswa merangkum pembelajaran yang telah dilakukan. Dosen tidak lupa mengulang kembali pengertian karangan argumentasi dan ciri-cirinya secara sekilas serta yang membedakannya dengan jenis karangan lain.

Ketiga, observasi dilakukan dosen untuk memeroleh data tentang aktivitas dosen dan mahasiswa. Data ini penting karena aktivitas dosen dan mahasiswa juga menjadi salah satu faktor yang menentukan keberhasilan pembelajaran.

Lembar observasi dosen juga dibagi menjadi tiga seperti pelaksanaannya, yaitu observasi pada tahap kegiatan awal, kegiatan inti, dan kegiatan akhir. Dari hasil observasi pada kegiatan awal, diketahui bahwa dosen selalu menyampaikan tujuan pembelajaran yang akan dicapai, dosen tidak memberikan motivasi kepada mahasiswa sebelum perkuliahan dimulai, dan dosen selalu memberikan apersepi terhadap mahasiswa walaupun belum maksimal.

Hasil observasi pada kegiatan inti menunjukkan bahwa dosen tidak menjelaskan secara rinci sistem pembagian kelompok. Hal ini membingungkan mahasiswa karena mereka sebelumnya sudah bergabung di kelompok asal. Dalam menyampaikan materi pelajaran, dosen sudah melakukannya dengan baik dan jelas serta tidak menghabiskan waktu terlalu lama. Dosen selalu memberikan kesempatan kepada mahasiswa untuk bertanya, tetapi kesempatan bertanya yang diberikan belum merata. Mahasiswa yang rajin bertanya dan memberikan pendapat adalah mahasiswa tertentu saja. Pembimbingan dosen tidak merata terhadap semua anggota kelompok ahli, padahal mahasiswa masih berdiskusi, tetapi dosen hanya meninjau dua kelompok.

Observasi berikutnya menunjukkan bahwa semua kelompok diberikan kesempatan untuk menyampaikan hasil diskusinya. Hasil diskusi tidak diberikan penilaian dengan angka, melainkan berbentuk umpan balik (feedback). Dosen hanya memberikan komentar terhadap hasil diskusi yang dipresentasikan kelompok masing-masing. Sebagai observasi terakhir pada kegiatan inti, dosen selalu memberikan penghargaan terhadap kelompok yang presentasinya paling baik.

Hasil observasi terhadap dosen yang dilakukan pada bagian kegiatan akhir menunjukkan bahwa dosen selalu menyimpulkan dan merangkum pembelajaran bersama-sama dengan mahasiswa. Tes hanya diberikan pada pertemuan kedua. Dosen memberikan tugas kepada mahasiswa hanya pada pertemuan pertama; sedangkan pada pertemuan kedua, tidak ada tugas untuk dilakukan mahasiswa di rumah. 
Observasi yang dilakukan terhadap mahasiswa menunjukkan bahwa tidak satu pun mahasiswa yang membaca materi pelajaran sebelum perkuliahan dimulai. Hal ini disebabkan karena mahasiswa belum mendapatkan modul ketika perkuliahan pertemuan pertama dimulai. Dalam berdisksusi, masih banyak mahasiswa yang tidak serius sehingga menyulitkan mereka untuk menyampaikan hasil diskusinya kepada teman di kelompok asal. Dalam bertanya, hanya sedikit mahasiswa yang berani bertanya, dan itu pun hanya mahasiswa tertentu, padahal dosen sudah memberikan kesempatan bertanya. Ada tiga orang mahasiswa yang mau menanggapi pertanyaan atau pernyataan dari teman atau dosennya.

Secara umum, mahasiswa tampak memperhatikan penjelasan dosen dengan baik tetapi hanya sedikit yang membuat catatancatatan penting selama perkuliahan. Dalam mengerjakan tugas membuat karangan, masih banyak mahasiswa yang bertanya-tanya kepada teman sebelahnya sehingga mengganggu teman yang sedang konsentrasi menulis.

Selain hasil observasi terhadap dosen dan mahasiswa sebagaimana yang telah diuraikan sebelumnya, mahasiswa juga ditugaskan untuk membuat karangan argumentasi maksimal dua paragraf. Waktu yang diberikan untuk menyelesaikannya hanya 25 menit dan mahasiswa bebas memilih topik. Tabel 2 adalah penilaian terhadap hasil karangan argumentasi mahasiswa UT Pekanbaru pada Siklus I pertemuan kedua.
Tabel 2. Hasil Tes Kemampuan Menulis Karangan Argumentasi Mahasiswa Semester VI UT Pekanbaru

\begin{tabular}{|c|c|c|c|c|c|c|}
\hline \multirow[t]{2}{*}{ No } & \multicolumn{4}{|c|}{ Nilai } & \multirow{2}{*}{$\begin{array}{c}\text { Skor } \\
5\end{array}$} & \multirow{2}{*}{$\begin{array}{c}\text { Kategor } \\
6\end{array}$} \\
\hline & 1 & 2 & 3 & 4 & & \\
\hline 1 & 60 & 73 & 65 & 62 & 66,60 & Sedang \\
\hline 2 & 64 & 60 & 65 & 62 & 62,20 & Sedang \\
\hline 3 & 80 & 82 & 78 & 80 & 80,40 & Tinggi \\
\hline 4 & 80 & 79 & 83 & 70 & 78,20 & Tinggi \\
\hline 5 & 72 & 68 & 64 & 66 & 67,60 & Sedang \\
\hline 6 & 64 & 66 & 65 & 60 & 64,20 & Sedang \\
\hline 7 & 60 & 66 & 68 & 60 & 64,00 & Sedang \\
\hline 8 & 62 & 64 & 70 & 78 & 67,60 & Sedang \\
\hline 9 & 65 & 66 & 65 & 65 & 65,40 & Sedang \\
\hline 10 & 78 & 80 & 73 & 68 & 75,80 & Tinggi \\
\hline 11 & 64 & 60 & 65 & 62 & 62,20 & Sedang \\
\hline 12 & 65 & 63 & 64 & 66 & 64,20 & Sedang \\
\hline 13 & 70 & 64 & 68 & 68 & 66,80 & Sedang \\
\hline 14 & 76 & 65 & 66 & 74 & 69,20 & Sedang \\
\hline 15 & 64 & 64 & 62 & 70 & 64,80 & Sedang \\
\hline 16 & 75 & 66 & 68 & 82 & 71,40 & Tinggi \\
\hline 17 & 68 & 62 & 68 & 62 & 64,40 & Sedang \\
\hline 18 & 62 & 64 & 64 & 60 & 62,80 & Sedang \\
\hline 19 & 61 & 63 & 68 & 66 & 64,20 & Sedang \\
\hline 20 & 66 & 64 & 70 & 70 & 66,80 & Sedang \\
\hline 21 & 68 & 78 & 82 & 72 & 75,60 & Sedang \\
\hline 22 & 64 & 68 & 70 & 68 & 67,60 & Sedang \\
\hline & 67 & & 67,50 & 68,68 & 67,77 & 67,82 \\
\hline
\end{tabular}

Ket:

$1=$ Tema/Topik Karangan (20\%)

$2=I s i(40 \%)$

$3=E Y D(20 \%)$

4 = Sistematika Penulisan (20\%)

Berdasarkan Tabel 2, hanya 4 orang $(18,18 \%)$ yang berada pada kategori tinggi dan 18 orang $(81,82)$ masih berada pada kategori rendah. Tidak ada mahasiswa yang berada pada posisi rendah dan sangat rendah. 
Ketidakberhasilan ini tidak sekadar tentang perolehan skor hasil belajar mahasiswa, tetapi lebih pada proses pembelajaran yang belum berjalan sesuai dengan yang direncanakan dosen. Teknik Jigsaw tidak terlaksana sebagaimana langkah-langkah yang ada pada teknik tersebut. Secara keseluruhan, nilai ratarata kelas mencapai 67,82 di bawah KKM. Hasil ini sangat mengecewakan dan belum sesuai dengan harapan sehingga penelitian dilanjutkan ke siklus berikutnya.

Keempat, tahap refleksi. Setelah mengetahui perolehan nilai karangan argumentasi mahasiswa, dosen dan teman sejawat langsung berdiskusi untuk merefleksi pembelajaran yang telah usai. Pada pertemuan kedua, dosen merasa telah berusaha maksimal dan juga telah memperbaiki kelemahan-kelemahan yang terjadi pada pertemuan pertama. Namun, hasil yang diperoleh belum sesuai dengan harapan. Setelah didiskusikan, diduga yang menyebabkan rendahnya kemampuan menulis mahasiswa adalah tidak ditentukannya tema oleh dosen.

Seperti diuraikan sebelumnya, materi bahasan pada pertemuan 2 adalah tentang karangan argumentasi. Dari hasil pekerjaan mahasiswa, terlihat bahwa sebagian mahasiswa belum mengutarakan pendapat-pendapatnya dalam karangan tersebut sebagai ciri dari karangan argumentasi. Sebagian mahasiswa lagi sudah mengutarakan pendapat-pendapatnya yang dilengkapi dengan data sehingga seperti beretorika. Akibatnya belum terlihat karakteristik karangan argumentasi.

Berdasarkan observasi teman sejawat bahwa mahasiswa lama mencari topik yang menarik, dan banyak yang berdiskusi dengan temannya sehingga menyita waktu. Waktu yang diberikan untuk menyelesaikan karangan hanya 25 menit; sementara 10 sampai 12 menit pertama mahasiswa masih bingung menentukan tema. Hal lain yang dicurigai sebagai penyebab rendahnya kemampuan menulis mahasiswa adalah dalam diskusi kelompok ahli di mana sebagian mahasiswa belum serius dan masih menggunakan waktu yang seyogianya untuk berdiskusi tetapi justru digunakan mengobrol dengan temannya. Dari hasil diskusi tersebut juga terlihat hanya dua atau tiga orang yang mengerjakan tugas-tugas saat diskusi di kelompok ahli. Hal inilah yang akan dijadikan fokus perbaikan pada siklus II.

Kemampuan menulis mahasiswa pada siklus I yang dilakukan dengan menerapkan model pembelajaran kooperatif tipe Jigsaw belum sepenuhnya dapat ditingkatkan. Menulis memang merupakan kegiatan yang kompleks karena penulis dituntut untuk dapat menyusun ide/gagasan dan mengorganisasikannya dalam formulasi ragam bahasa tulis (Hertiavi, 2010: 5). Dibalik kerumitannya, menulis mengandung banyak manfaat bagi pengembangan mental, intelektual, dan sosial siswa. Melalui kegiatan menulis paragraf, mahasiswa dapat mengkomunikasikan ide, gagasan, dan pengalamannya.

\section{Siklus II}

Pelaksanaan siklus II didasarkan atas hasil yang diperoleh pada siklus I. Pada siklus I, mahasiswa yang memeroleh nilai di atas KKM hanya 5 orang dan nilai rata-rata kelas adalah 67,82 . Berdasarkan hasil tersebut, dosen dan teman sejawat sepakat untuk melanjutkan ke siklus II. Siklus II juga dilaksanakan selama dua kali pertemuan dengan materi yang berbeda.

Pertemuan Ketiga (Sabtu, 7 November 2015) Pertemuan ketiga merupakan awal dimulainya siklus II. Pokok bahasan yang dibahas pada siklus II ini adalah Paragraf II dengan subpokok bahasan karangan eksposisi. Model pembelajaran yang diterapkan juga sama dengan model pembelajaran sebelumnya, yaitu model pembelajaran kooperatif tipe Jigsaw. Pelaksanaan pembelajaran pada 
pertemuan ketiga ini juga berpedoman pada langkah-langkah PTK, yaitu: perencanaan, pelaksanaan, observasi, dan refleksi.

Pertama, yaitu tahap perencanaan. Dosen menyiapkan RPP untuk menjadi pedoman pada saat pelaksanaan pembelajaran. RPP yang dibuat sesuai dengan materi yang dipelajari, yaitu karangan eksposisi. Selain menyiapkan RPP dan perangkat pembelajaran lainnya, dosen juga menyiapkan beberapa karangan eksposisi sebagai media pembelajaran yang akan digunakan. Lembar observasi, baik terhadap mahasiswa maupun dosen, yang digunakan pada siklus I dicetak ulang untuk digunakan kembali pada pertemuan ketiga. Agar pembelajaran berjalan dengan baik, dosen kembali menjelaskan karangan eksposisi kepada mahasiswa. Selain itu, dosen juga berulang kali menekankan kembali proses pembentukan kelompok dalam tipe Jigsaw.

Kedua, pelaksanaan proses pembelajaran mengacu pada RPP yang telah disiapkan pada tahap perencanaan. Proses pembelajaran dibagi ke dalam tiga kegiatan, yaitu kegiatan awal, kegiatan inti, dan kegiatan akhir.

Sebagai pendahuluan kegiatan awal, dosen dan teman sejawat memasuki kelas dengan penuh keyakinan akan dapat mengatasi kegagalan dan memperbaiki/menyempurnakan beberapa kelemahan yang terjadi pada siklus I. Seperti biasa, dosen langsung menuju mejanya dan teman sejawat duduk di bagian belakang. Dosen memberi salam dan menyapa mahasiswa. Mahasiswa pun menjawab salam dosen secara serentak. Kemudian, dosen memberikan motivasi dan menghubungkan materi bahasan dengan materi bahasan pada pertemuan sebelumnya. Selanjutnya, dosen mengajukan beberapa pertanyaan apersepsi dan pengenalan materi. Sebagai pembuka kelas, semuanya tampak berjalan semakin lancar dan suasana kelas juga semakin menyenangkan.
Untuk mengawali kegiatan inti, dosen mengadakan tanya jawab singkat dengan mahasiswa tentang karangan eksposisi. Namun, mahasiswa kelihatan belum memiliki pengetahuan awal tentang materi tersebut. Sebagian besar mahasiswa hanya diam saat dosen mengajukan pertanyaan dan hanya ada dua orang mahasiswa yang berusaha menanggapi. Berdasarkan diskusi tersebut, dosen mulai memasuki materi dengan menjelaskan tentang pengertian karangan eksposisi, ciri-cirinya, strukturnya, dan aspekaspek lainnya.

Setelah penjelasan, mahasiswa dibagi menjadi 4 kelompok asal seperti pada pertemuan sebelumnya. Pada pertemuan ketiga, anggota setiap kelompok diacak dan tidak sama dengan dua pertemuan sebelumnya sehingga mereka memiliki kelompok asal yang baru. Dosen melanjutkan kegiatan pembelajaran dengan membagikan materi yang berbeda kepada masing-masing anggota kelompok.

Langkah selanjutnya adalah mahasiswa diinstruksikan untuk bergabung di kelompok ahli. Mahasiswa yang mendapatkan materi yang sama bergabung dalam kelompok ahli. Di kelompok ahli, mereka mendiskusikan materi yang telah dibagikan dan masing-masing mahasiswa membuat catatan-catatan penting. Catatan-catatan tersebut akan dijadikan sebagai bahan laporan individu. Namun, sebelum berdiskusi di kelompok ahli, dosen memberikan panduan aspek-aspek yang akan didiskusikan. Hal ini bertujuan agar diskusi lebih fokus. Aspekaspek yang didiskusikan menurut arahan dosen adalah mencari kalimat yang menjelaskan tentang sesuatu, kalimat-kalimat yang bersifat informatif, fakta-fakta yang digunakan untuk kontribusi, fakta-fakta konkritisasi, dan jawaban atas pertanyaan, apa, siapa, di mana, kapan, mengapa, dan bagaimana. 
Setelah berdiskusi dan memiliki butir-butir penting dan dianggap lengkap, maka mahasiswa kembali bergabung ke kelompok asal. Di kelompok asal, setiap anggota melaporkan secara singkat hasil diskusi mereka di kelompok ahli ke kelompok asal. Kelompok asal merangkum semua hasil diskusi anggotanya di kelompok ahli. Setelah informasi lengkap dari materi-materi yang berbeda dari kelompok ahli, kelompok asal menyusun bahan presentasi kelompok. Kemudian, setiap kelompok asal mendapatkan giliran untuk mempresentasikan hasil diskusinya. Ketika salah satu kelompok asal mempresentasikan bahan presentasinya, berdiskusi, kelompok lain menanggapi dan memberikan masukan. Setelah presentasi kelompok usai, dosen kemudian memberikan penghargaan terhadap kelompok yang presentasinya paling baik. Dosen juga memberikan masukan dan saran terhadap semua kelompok agar di pertemuan selanjutnya mahasiswa melakukan presentasi yang lebih baik.

Sebagai penutup pembelajaran, dosen bersama-sama dengan mahasiswa menyimpulkan pembelajaran. Dosen kembali memberikan penekanan-penekanan terhadap materi yang dianggap penting. Sebelum kelas berakhir, dosen memberikan tugas membuat karangan eksposisi untuk dikerjakan di rumah.

Ketiga, tahap observasi. Berdasarkan catatan-catatan teman sejawat pada lembar observasinya, diketahui bahwa dosen dalam menyampaikan materi pembelajaran sudah sangat baik. Penjelasannya lengkap dan sangat terstruktur. Langkah-langkah tipe Jigsaw juga sudah diterapkan sesuai dengan urutanurutannya. Namun, masih terdapat kelemahan, yaitu dosen kurang memberikan bimbingan yang merata terhadap setiap kelompok pada saat diskusi.
Terkait dengan observasi terhadap aktivitas mahasiswa, diketahui bahwa masih ada sebagian kecil mahasiswa yang hanya mengandalkan catatan-catatan dari temannya ketika mereka berdiskusi pada kelompok ahli. Akibatnya mereka kesulitan ketika harus melaporkan kepada kelompok asalnya dan informasi yang disampaikan menjadi tidak lengkap.

Keempat, refleksi dilakukan sesaat pembelajaran usai. Dosen dan teman sejawat segera berdiskusi terkait pembelajaran yang telah dilalui. Dari hasil diskusi dengan teman sejawat, diketahui bahwa masih terdapat hal-hal yang harus diperbaiki, di antaranya adalah dosen tidak memberikan bimbingan yang maksimal ketika mahasiswa diskusi. Di samping itu, ada juga mahasiswa yang tidak terlibat langsung dalam diskusi karena hanya mengandalkan catatan-catatan temannya.

\section{Pertemuan Keempat (Sabtu, 14 November 2015)}

Pertemuan keempat merupakan pertemuan terakhir siklus II. Pertemuan ini pun dilaksanakan berdasarkan jadwal terakhir perkuliahan di UT Pekanbaru. Kelemahan-kelemahan yang masih terjadi pada pertemuan sebelumnya akan diperbaiki. Pertemuan keempat juga mengacu pada tahapan-tahapan dalam pelaksanaan PTK, yaitu perencanaan, pelaksanaan, observasi, dan refleksi.

Pertama, tahap perencanaan. Seperti pembelajaran sebelumnya, pada pertemuan keempat, dosen juga merencanakan pembelajaran bersama teman sejawat. Pokok bahasan masih sama dengan pertemuan ketiga, yaitu Paragraf II, tetapi subpokok bahasan yang berbeda. Pada pertemuan keempat, pokok bahasannya adalah karangan persuasi. Jadi, dosen menyiapkan RPP yang sesuai dengan materi tersebut. Selain menyiapkan RPP, dosen 
juga menyediakan enam karangan persuasi (sesuai dengan jumlah anggota pada kelompok asal). Dosen kembali menjelaskan tipe Jigsaw yang akan diterapkan agar tidak ada lagi keraguan dalam pembentukan kelompok. Dosen juga menjelaskan ulang materi bahasan tentang karangan persuasi tersebut.

Kedua, tahap pelaksanaan terdiri dari kegiatan awal, kegiatan inti, dan kegiatan akhir. Saat memasuki kelas, dosen sangat senang dan percaya diri melaksanakan kegiatan pembelajaran pada pertemuan keempat dengan menerapkan tipe Jigsaw. Seperti biasa, dosen memeriksa kehadiran mahasiswa, dan ternyata semua mahasiswa hadir dan siap menerima perkuliahan. Dosen mengajak mahasiswa bertanya jawab dengan tujuan untuk menghubungkan materi yang dibahas dengan materi yang telah dibahas sebelumnya. Kemudian, dosen memotivasi mahasiswa dan memberikan apersepsi agar mahasiswa lebih bersemangat.

Kegiatan inti merupakan aplikasi dari perencanaan yang disusun dosen dan teman sejawat. Penyusunan RPP pada pertemuan keempat didasarkan atas kelemahan-kelemahan pada pertemuan sebelumya dengan tujuan untuk lebih menyempurnakan proses pembelajaran. Mengawali kegiatan inti, dosen mengadakan tanya jawab dan diskusi singkat dengan mahasiswa terkait dengan karangan persuasi. Sebelumnya, mahasiswa sudah diberikan informasi bahwa materi pada pertemuan keempat adalah karangan persuasi.

Hampir semua mahasiswa sudah membaca materi karena pada pertemuan sebelumnya dosen sudah memberikan motivasi kepada mahasiswa agar membaca materi yang akan dibahas di rumah. Dengan demikian, mahasiswa sudah bisa terlibat aktif dalam pembelajaran. Hal ini terlihat ketika dosen mengajukan pertanyaan, hampir semua mahasiswa berusaha memberikan jawaban. Begitu juga ketika berdiskusi, semua mahasiswa ingin memberikan komentar. Dengan situasi seperti ini, kelas lebih ribut dari biasanya. Namun, dosen sangat menikmati karena perhatian mahasiswa sudah terfokus kepada pembelajaran. Tidak ada lagi mahasiswa yang mengobrol dan sibuk sendiri. Namun, komentar dan jawaban yang diberikan mahasiswa masih ada yang kurang berdasar. Walau demikian, dosen tetap senang, setidaknya mahasiswa sudah terfokus pada pembelajaran.

Setelah berdiskusi dan mengadakan tanya jawab, dosen menginstruksikan mahasiswa untuk bergabung di kelompok asal yang sama dengan kelompok kecil pada pertemuan ketiga. Setelah semua mahasiswa berada di kelompok asal, dosen kemudian membagikan materi yang berbeda kepada setiap mahasiswa, yaitu berupa beberapa contoh karangan persuasif. Mahasiswa membentuk kelompok ahli dan berdiskusi tentang karangan persuasi sesuai dengan arahan dosen. Sebelum berdiskusi, dosen memberikan arahan tentang hal-hal yang perlu didiskusikan, yaitu kalimat yang berusaha meyakinkan pembaca tentang topik yang ditulisnya, mencari kalimat-kalimat ajakan, kalimat-kalimat penulis yang berusaha menghindari konflik, kalimat penjelasan dan menarik perhatian serta kepercayaan pembaca, dan kalimat yang mengandung alasan-alasan yang kuat dan meyakinkan pembaca.

Dengan adanya arahan seperti ini, diskusi kelompok ahli yang dilakukan mahasiswa lebih terfokus dan waktu yang diberikan bisa dimaksimalkan dengan baik. Ketika berdiskusi, mahasiswa menulis beberapa catatan penting terkait dengan materi dan sesuai dengan arahan dosen. Setelah berdiskusi di kelompok ahli, setiap anggota kembali ke kelompok asal. Di kelompok asal, setiap anggota berusaha memberikan informasi yang lengkap kepada teman-temannya. Semua informasi dikumpulkan 
untuk disiapkan sebagai bahan presentasi. Di bagian akhir kegiatan inti, setiap kelompok diberikan kesempatan untuk mempresentasikan hasil diskusinya. Ketika satu kelompok menyajikan presentasinya, kelompok lain diberikan kesempatan untuk bertanya, memberikan masukan, dan memberikan penguatan terhadap hasil diskusi.

Pada kegiatan akhir, dosen memberikan komentar terhadap pendapat-pendapat mahasiswa ketika presentasi kelompok. Dosen memberikan penghargaan kepada kelompok yang presentasinya paling bagus dan informasinya paling lengkap. Kemudian, dosen dan mahasiswa merangkum pembelajaran bersama. Terakhir, dosen menutup pembelajaran dengan memberikan salam.

Ketiga, observasi dari dosen, untuk memeroleh data tentang aktivitas dosen dan mahasiswa, teman sejawat melakukan observasi selama proses pembelajaran berlangsung di siklus II. Observasi terhadap aktivitas dosen dilakukan berdasarkan tiga langkah dalam pembelajaran, yaitu: kegiatan awal, kegiatan inti, dan kegiatan akhir. Observasi terhadap kegiatan dosen pada kegiatan awal menunjukkan bahwa dalam membuka pembelajaran telah dilakukan dengan sempurna. Dosen menyampaikan tujuan pembelajaran yang akan dicapai pada pertemuan keempat dengan jelas. Dosen juga telah memberikan motivasi dan apersepsi kepada mahasiswa pada setiap pertemuan dan menghubungkan materi sebelumnya dengan materi yang sedang dibahas.

Pada kegiatan inti, dosen sudah menjelaskan secara rinci teknik pembagian kelompok asal dan kelompok ahli. Materi karangan persuasi disampaikan dosen dengan sangat jelas dan rinci. Dosen menjelaskan pengertian dan ciri-ciri karangan persuasi disertai dengan pemberian contoh secara efektif. Jika sebelumnya, hanya sedikit mahasiswa yang mau bertanya, maka pada pertemuan keempat ini, semua mahasiswa sudah terlibat secara aktif dalam pembelajaran. Dosen tetap membatasi, mengingat ketersediaan waktu, tetapi penggunaan waktu yang diberikan sudah sangat merata. Pada saat pembimbingan diskusi, dosen menghampiri semua kelompok untuk mengontrol diskusi dan memberikan arahan serta membantu kesulitan-kesulitan yang dihadapi mahasiswa. Setiap kelompok diberikan penghargaan berupa feedback dan evaluasi terhadap hasil presentasinya. Presenter terbaik pada siklus II ini diberikan hadiah berupa pena untuk memotivasi mahasiswa lain agar berani menyampaikan presentasi.

Terkait observasi terhadap mahasiswa pada siklus II, baik pertemuan ketiga maupun keempat, mahasiswa telah memiliki pengetahuan awal terhadap materi bahasan sebelum pembelajaran dimulai. Hal ini menjadi penekanan dosen agar mahasiswa membaca modul di rumah. Dalam berdiskusi, mahasiswa sudah terlihat aktif, saling bekerja sama, dan saling membantu. Mahasiswa juga terlihat sangat aktif dan fokus terhadap pembelajaran, baik pada saat dosen menjelaskan maupun pada saat mereka berdiskusi. Mahasiswa juga sudah terlihat sangat percaya diri dalam mengerjakan tugas yang diberikan pada pertemuan keempat. Saat mereka mulai mengerjakan tugas, tidak perlu lagi bertanya kepada teman sebelah sehingga tidak ada mahasiswa yang merasa terganggu oleh temannya. Pada pertemuan keempat, mahasiswa ditugasi untuk membuat karangan persuasi dengan tema pendidikan. Waktu yang diberikan adalah 20 menit dan berikut adalah hasil penilaian terhadap karangan mahasiswa. 
Tabel 3. Hasil Tes Kemampuan Menulis Karangan Persuasi Mahasiswa Semester VI UT Pekanbaru

\begin{tabular}{|c|c|c|c|c|c|c|}
\hline \multirow[t]{2}{*}{ No } & \multicolumn{4}{|c|}{ Nilai } & \multirow{2}{*}{$\frac{\text { Skor }}{5}$} & \multirow{2}{*}{$\frac{\text { Kategori }}{6}$} \\
\hline & 1 & 2 & 3 & 4 & & \\
\hline 1 & 82 & 68 & 78 & 87 & 76,6 & Tinggi \\
\hline 2 & 66 & 64 & 70 & 70 & 66,8 & Sedang \\
\hline 3 & 82 & 86 & 78 & 88 & 84 & Tinggi \\
\hline 4 & 78 & 80 & 86 & 80 & 80,8 & Tinggi \\
\hline 5 & 68 & 79 & 83 & 80 & 77,8 & Tinggi \\
\hline 6 & 78 & 74 & 72 & 80 & 75,6 & Sedang \\
\hline 7 & 70 & 70 & 76 & 77 & 72,6 & Sedang \\
\hline 8 & 78 & 66 & 80 & 76 & 73,2 & Sedang \\
\hline 9 & 70 & 68 & 78 & 70 & 70,8 & Sedang \\
\hline 10 & 80 & 84 & 70 & 70 & 77,6 & Tinggi \\
\hline 11 & 70 & 76 & 80 & 70 & 74,4 & Sedang \\
\hline 12 & 70 & 73 & 68 & 70 & 70,8 & Sedang \\
\hline 13 & 68 & 82 & 70 & 74 & 75,2 & Sedang \\
\hline 14 & 70 & 80 & 76 & 66 & 74,4 & Sedang \\
\hline 15 & 67 & 68 & 70 & 80 & 70,6 & Sedang \\
\hline 16 & 78 & 70 & 78 & 80 & 75,2 & Sedang \\
\hline 17 & 80 & 82 & 68 & 68 & 76 & Tinggi \\
\hline 18 & 70 & 74 & 78 & 68 & 72,8 & Sedang \\
\hline 19 & 76 & 78 & 80 & 76 & 77,6 & Tinggi \\
\hline 20 & 78 & 80 & 68 & 70 & 75,2 & Sedang \\
\hline 21 & 80 & 84 & 78 & 75 & 80,2 & Tinggi \\
\hline 22 & 76 & 76 & 78 & 78 & 76,8 & Tinggi \\
\hline & 74 & & 75,55 & 75,59 & 75,14 & 75,23 \\
\hline
\end{tabular}

Ket:

$$
\begin{aligned}
& 1=\text { Tema/Topik Karangan (20\%) } \\
& 2=I \text { Isi (40\%) } \\
& 3=\text { EYD (20\%) } \\
& 4=\text { Sistematika Penulisan (20\%) }
\end{aligned}
$$

Tabel 3 mengemukakan bahwa mahasiswa yang berada pada kategori tinggi sudah mencapai 9 orang $(40,90 \%)$, dan 13 orang lainnya berada pada kategori sedang. Hasil ini sudah menggembirakan, karena selain skor hasil belajar yang mengalami peningkatan, proses pembelajaran juga sudah berjalan sesuai dengan yang direncanakan dosen dan teman sejawat. Selain itu, pelaksanaan teknik Jigsaw juga sudah sesuai dengan langkah-langkahnya. Pada saat pembagian kelompok, tidak lagi diperlukan waktu yang lama seperti pada siklus I. Secara keseluruhan nilai rata-rata kelas mencapai 75,23. Berdasarkan perolehan hasil belajar tersebut dapat dikatakan bahwa penerapan model pembelajaran kooperatif tipe Jigsaw telah dapat meningkatkan kemampuan menulis mahasiswa sehingga dosen dan teman sejawat bersepakat bahwa penelitian tidak perlu dilanjutkan ke siklus berikutnya.

Keempat, tahap refleksi. Sesaat setelah pertemuan keempat usai, dosen dan teman sejawat masih melakukan refleksi terhadap pembelajaran meskipun antara dosen dan teman sejawat sudah bersepakat tidak melanjutkan penelitian ke siklus berikutnya. Refleksi dilakukan dengan berdiskusi membahas proses pembelajaran yang telah dilalui. Berdasarkan hasil refleksi pertemuan keempat, diketahui bahwa hampir semua proses pembelajaran sudah berjalan sesuai dengan perencanaan. Dosen sangat senang memainkan perannya, baik sebagai guru maupun sebagai peneliti. Kelemahan-kelemahan yang terjadi pada pertemuan sebelumnya pun sudah bisa diatasi dengan baik. Kebingungan mahasiswa mencaricari topik karangan tidak terjadi lagi karena topik karangan sudah ditentukan oleh dosen. Terlihat bahwa mahasiswa sudah bisa langsung mulai menulis sehingga waktu tidak terbuang.

Pada diskusi kelompok ahli pun demikian, semua mahasiswa terlihat lebih serius dan fokus terhadap materi yang didiskusikan. Mereka juga telah membagi tugas kepada masing-masing anggota kelompok ahli untuk dikerjakan sehingga tidak ada lagi orang yang mendominasi pada kelompok ahli tersebut. Semua anggota kelompok ahli sudah terlibat dalam pembelajaran 
dan mengerjakan tugas sesuai bagiannya sehingga tugas-tugas yang diberikan kepada kelompok ahli bisa lebih cepat diselesaikan.

Pada saat presentasi kelompok, terlihat bahwa semua kelompok telah mengerjakan tugas dengan baik. Hampir semua mahasiswa terlihat ingin memberikan masukan atau mengajukan pertanyaan pada saat presentasi kelompok tersebut. Berdasarkan hal tersebut, dosen dan teman sejawat menyimpulkan bahwa pembelajaran sudah dilaksanakan sesuai dengan perencanaan. Berdasarkan hasil penelitian yang dipaparkan pada bagian sebelumnya, diketahui bahwa penerapan tipe jigsaw dapat meningkatkan kemampuan menulis mahasiswa.

Peningkatan kemampuan menulis tersebut terlihat dari perolehan skor dari siklus I dan siklus II. Dalam pemilihan tema/topik karangan, ratarata kelas pada siklus I adalah 67,64 dan pada siklus II meningkat menjadi 74,32. Perolehan skor item isi atau kualitas karangan pada siklus I adalah 67,50 dan pada siklus II meningkat menjadi 75,55. Perolehan skor EYD pada siklus I adalah 68,68 dan pada siklus II meningkat menjadi 75,59 . Perolehan skor item sistematika penulisan pada siklus I adalah 67,77 dan pada siklus II meningkat menjadi 75,14. Secara keseluruhan rata-rata kelas pada siklus I adalah 67,82 dan pada siklus II menjadi 75,23 . Untuk lebih jelasnya peningkatan kemampuan menulis mahasiswa ini disajikan pada tabel dan grafik berikut ini.

Tabel 4. Hasil Tes Kemampuan Menulis Mahasiswa UT Pekanbaru Siklus I dan II

\begin{tabular}{cccccc}
\hline Siklus $\begin{array}{c}\text { Pemilihan } \\
\text { Tema }\end{array}$ & Isi & EYD & $\begin{array}{c}\text { Sistematika } \\
\text { Penulisan }\end{array}$ & $\begin{array}{c}\text { Rata- } \\
\text { rata } \\
\text { Kelas }\end{array}$ \\
\hline Siklus I 67,64 & 67,50 & 68,68 & 67,77 & 67,82 \\
\hline Siklus II 74,32 & 75,55 & 75,59 & 75,14 & 75,23 \\
\hline
\end{tabular}

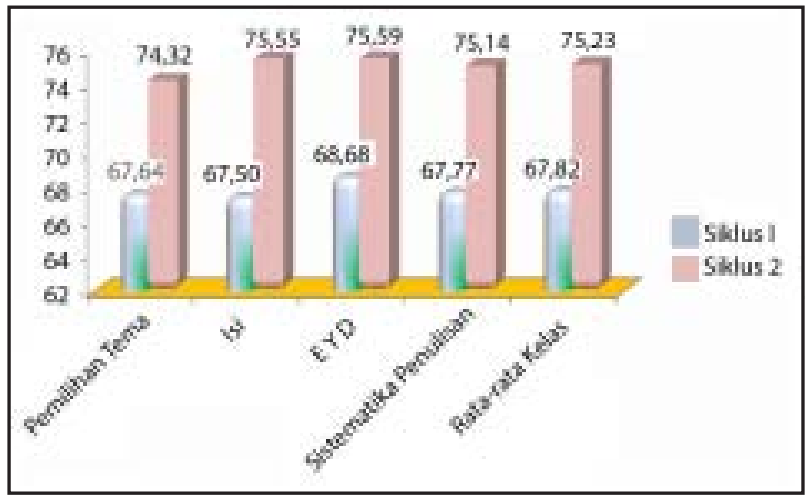

Gambar 2. Peningkatan Kemampuan Menulis Mahasiswa UT Pekanbaru Siklus I dan II

Pada siklus I, pertemuan pertama dan kedua pelaksanaan perbaikan pembelajaran, diketahui bahwa nilai rata-rata mahasiswa mencapai 67,82 dan belum mencapai KKM yang ditentukan yaitu 70. Belum adanya peningkatan kemampuan menulis mahasiswa pada siklus I tersebut disebabkan oleh belum maksimalnya penerapan tipe jigsaw. Pada siklus I terutama pertemuan pertama masih sangat sulit mengarahkan mahasiswa dalam pembagian kelompok ahli. Hal ini disebabkan mahasiswa belum punya pengalaman dengan pembagian kelompok seperti pada tipe jigsaw.

Pembagian kelompok sebelumnya dilaksanakan secara konvensional. Mahasiswa dibagi menjadi kelompok-kelompok belajar dan kemudian diberikan materi untuk dibahas. Selanjutnya, mahasiswa berdiskusi dalam kelompok. Sistem pembagian tugas dalam kelompok seperti itu menyebabkan mahasiswa banyak yang tidak serius dan tidak semuanya terlibat dalam pembelajaran. Pada siklus I pertemuan kedua, mahasiswa sudah mulai paham dengan pembagian kelompok dan tugastugas yang harus mereka kerjakan. Namun belum semua mahasiswa memiliki rasa tanggung jawab positif terhadap tugas-tugasnya, mereka juga belum menyadari sepenuhnya bahwa mereka akan mengajarkan materi yang dibahas pada kelompok ahli ke kelompok asal masingmasing. 
Pada siklus II, mahasiswa sudah paham dengan teknik pembagian kelompok dan tugas setiap individu pada tipe jigsaw. Pada pertemuan ketiga dan keempat, semua mahasiswa sudah mulai terlibat dalam pembelajaran. Mahasiswa mulai menyadari jika tidak serius, mereka tidak akan bisa menyampaikan hasil diskusi kelompok ahli ke kelompok asalnya masing-masing. Mahasiswa juga mulai menyadari bahwa ada saling ketergantungan positif dari setiap individu terhadap kelompoknya. Hal ini sesuai dengan pendapat Sudrajat (2008:1) bahwa pembelajaran kooperatif tipe Jigsaw adalah suatu tipe pembelajaran kooperatif yang terdiri dari beberapa anggota dalam satu kelompok yang bertanggung jawab atas penguasaan bagian materi belajar dan mampu mengajarkan materi tersebut kepada anggota lain dalam kelompoknya.

Menurut pengakuan mahasiswa, mereka sangat senang dan termotivasi dengan cara belajar seperti ini. Beberapa dari mahasiswa juga mengatakan, mereka harus mencari pengetahuan sendiri melalui diskusi dalam kelompok kecil.

Pada siklus II, seluruh mahasiswa juga terlihat aktif dan sibuk berusaha memahami materi yang menjadi bagiannya. Hal ini menunjukkan bahwa pemerataan materi sudah terlaksana dengan baik. Selain itu, mahasiswa juga lebih berani menyampaikan pendapat terhadap permasalahan yang dibahas. Hal ini terlihat saat salah satu kelompok asal mempresentasikan hasil diskusi mereka, kelompok lain berusaha menanggapi dan menyampaikan pendapat. Model pembelajaran tipe jigsaw telah dapat membelajarkan mahasiswa secara optimal dan mengaktifkan mahasiswa dalam belajar. Tastra, dkk. (2013: 4) menyatakan bahwa secara keseluruhan model pembelajaraan kooperatif tipe jigsaw memiliki keunggulan yang dapat menunjang hasil belajar menjadi lebih baik. Pertama, dosen berperan sebagai pendamping atau penolong dan mengarahkan diskusi pada kelompok ahli yang bertugas menjelaskan materi kepada rekan-rekannya. Kedua, pemerataan materi dapat dicapai dalam waktu yang lebih singkat. Ketiga, model pembelajaran tipe jigsaw dapat melatih untuk menyampaikan pendapat, baik dengan bahasa tulisan maupun lisan.

\section{SIMPULAN DAN SARAN}

\section{Simpulan}

Model pembelajaran kooperatif tipe Jigsaw terbukti dapat meningkatkan kemampuan menulis mahasiswa UT Pekanbaru yang dapat dilihat dari capaian hasil belajar mereka. Model pembelajaran kooperatif tipe Jigsaw juga terlihat telah dapat membelajarkan mahasiswa secara optimal. Melalui model ini, mahasiswa saling memiliki tanggung jawab positif terhadap materi yang menjadi bagiannya. Dengan demikian, mahasiswa harus mencari pengetahuan sendiri melalui diskusi dengan temannya di kelompok ahli dan setiap mahasiswa harus menguasai materi tersebut. Teknik Jigsaw telah membelajarkan mahasiswa secara optimal.

\section{Saran}

Melalui penelitian ini, ada tiga saran yang ingin disampaikan. Pertama, model pembelajaran kooperatif tipe Jigsaw telah terbukti dapat meningkatkan kemampuan menulis mahasiswa UT Pekanbaru. Oleh karena itu, disarankan kepada dosen-dosen dan tenaga pendidik lainnya untuk menggunakan model pembelajaran ini dalam menyampaikan materimateri yang sesuai kepada peserta didiknya. Kedua, kepada pengambil kebijakan agar dapat memberikan arahan kepada para dosen/guru/ tenaga pendidik untuk melaksanakan pembelajaran dengan menerapkan metode/ model/teknik pembelajaran yang lebih inovatif. Ketiga, kepada peneliti lain agar menjadikan hasil penelitian ini menjadi acuan untuk melaksanakan penelitian serupa. 


\section{PUSTAKA ACUAN}

Dewi, M. 2013. Penerapan Metode Jigsaw dalam Pembelajaran Membaca Teks Biografi pada Siswa Kelas XI SMA. ejournal.upi.edu, Vol. 1, No. 1, Juni, pp 25-34.

Gesarina, A. 2013. Peningkatan Kemampuan Menulis Teks Berita dengan Metode Investigasi Kelompok, ejournal.upi.edu, Vol. 1, No. 1, Juni, pp 1-8.

Hertiavi M.A., H. Langlang, dan S. Khanafiyah. 2010. Penerapan Model Pembelajaran Kooperatif Tipe Jigsaw Untuk Peningkatan Kemampuan Pemecahan Masalah Siswa SMP. Jurnal Pendidikan Fisika Indonesia. Vol. 6, No.I, pp 53-57.

Hidayat, S. 2011. Peningkatan Kemampuan Menulis Karangan Deskripsi dengan Menggunakan Media Gambar. Skripsi. Jakarta: Universitas Islam Negeri Syarif Hidayatullah.

Khadarsih, A. Laila. 2012. Upaya Meningkatkan Keterampilan Menulis Karangan Narasi dengan Media Gambar Seri pada Mata Pelajaran Bahasa Indonesia Kelas IV MI Al - Ihsan Medari Sleman Yogyakarta Tahun Ajaran 2011/2012. Skripsi. Yogyakarta: Universitas Islam Sunan Kalijaga.

Madya, Suwarsih. Penelitian Tindakan Kelas, [online]saidnazulfiqar.files.wordpress.com. diakses 8 Oktober 2016.

Masriyah, S. 2012. Penerapan Pembelajaran Kooperatif Tipe Jigsaw untuk Meningkatkan Hasil Belajar Siswa Kelas IV pada Pelajaran IPA. Skripsi. Jakarta: Universitas Islam Negeri Syarif Hidayatullah.

Mills, G.E. 2000. Action Research: A Guide for the Teacher Researcher. Columbus: Merrili, An Imprint of Prentice Hall.

Pratiwi, Herguhtya Dini. 2009. Pengaruh Pembelajaran Kooperatif Tipe Jigsaw terhadap Prestasi Belajar Siswa Kelas VII Di SMP Negeri I Batang Tahun Ajaran 2008/2009 (Studi Pada Mata Pelajaran Geografi Materi Pokok Bentuk-Bentuk Muka Bumi). Skripsi. Semarang: Universitas Negeri Semarang.

Rahmaeta, I. 2012. Penerapan Pembelajaran Kooperatif Tipe Jigsaw untuk Meningkatkan Aktivitas dan Hasil Belajar Siswa Kelas V SD Negeri 04 Bulu Pemalang. Skripsi. Semarang: Universitas Negeri Semarang.

Sopandi, W.M. 2013. Pembelajaran Fisika Berbantuan Media CD Pembelajaran Pori untuk Meningkatkan Prestasi Belajar Siswa SMPN 2 Klari. Skripsi. Universitas Pendidikan Indonesia. Diakses 6 Juni 2017.

Sudrajat, A. 2008. Cooperative Learning-teknik Jigsaw. akhmadsudrajat. wordpress.com. diakses 8 Oktober 2016.

Sulasdi, Risyani, dan Rahayu Pristiwati. 2011. Peningkatan Kemampuan Menulis Narasi dengan Media Gambar. Jurnal Penelitian Tindakan Kelas Decentralized Basic Education. Vol. Khusus, No. 1, pp 69—76.

Sutarno, Suyanto, dan Titik Indarti. 2011. Peningkatan Kemampuan Menulis Laporan melalui Model Pembelajaran Amati Petakan Informasi Kembangkan (APIK). Jurnal Penelitian Tindakan Kelas Decentralized Basic Education. Vol. Khusus, No. 1, pp 77-84.

Tastra, I Ketut, Marhaeni A.A.I.N, dan Lasmawan I Wayan. 2013. Pengaruh Penggunaan Model Pembelajaran Kooperatif Tipe Jigsaw terhadap Hasil Belajar Menulis Ditinjau dari Motivasi Berprestasi Siswa Kelas VII SMP Negeri 4 Mendoyo. e- jurnal Program Pascasarjana Universitas Pendidika Ganesha. Vol. 3 No.1, pp 1-12. Uno, Hamzah B. dan Nurdi Mohamad. 2012. Belajar dengan Pendekatan PAILKEM. Jakarta: Bumi Aksara. Wardhani IGAK dan Wihardit Kuswaya. 2007. Penelitian Tindakan Kelas. Jakarta: Universitas Terbuka.

\section{UCAPAN TERIMA KASIH}

Penulis menucapkan terima kasih kepada semua pihak yang membantu dalam penelitian ini. Pertama, teman sejawat yang selalu membantu dalam pengumpulan data dan kepada mahasiswa yang menjadi objek penelitian ini. Kedua, pihak UT yang memfasilitasi terlaksananya penelitian ini. Ketiga, teman-teman peneliti di Balai Bahasa Riau yang membantu dalam pelaporan penelitian ini. 